\title{
Sodium chloride substitution in industrial white slice diary bread
}

\section{Debora Conde Molina1, Carla Quevedo ${ }^{1}$, Valeria Arqueros ${ }^{2}$}

\author{
1 - National Technological University, Campana, Argentina \\ 2 - Granotec Argentina, Garin, Argentina
}

\section{Keywords:}

Bread

Sodium chloride

Rheology

Mixolab

Texture

\section{Article history:}

Received

15.07.2020

Received in revised

form 12.11.2020

Accepted

25.03.2021

\section{Corresponding \\ author:}

Debora Conde

Molina

E-mail:

dconde@

frd.utn.edu.ar

DOI:

$10.24263 / 2304-$

974X-2021-10-1-5

\section{Abstract}

Introduction. The effect of sodium chloride replacement was studied in industrial white slice diary bread, promoting a technological approach to decrease the sodium content from bakery products in order to respond to the World Health Organization's recommendation to reduce dietary salt intake.

Materials and methods. Granolife CV Sustisal 100 (GCVS100) was evaluated as sodium chloride substitute analyzing the dough fermentative properties by Rheofermentometer, and the dough behaviour properties on mixing-heating-cooling by Mixolab. Additionally, loaf specific volume and texture profile were considered as baking quality parameters.

Results and discussion. The addition of GCVS100 or $\mathrm{NaCl}$ to wheat flour dough led to decrease gas production during fermentation stage. However, they significantly increased the coefficient of gas retention, promoting the improvement of the gluten network and allowing to get a dough development curve similar to dough flour. Additionally, both ingredients changed several flour dough parameters in Mixolab. Water absorption was decreased, dough stability was prolonged, gelatinization process (C3-C2) was reduced, stability of the starch gel when heated (C4C3) was improved and retrogradation of the starch was increased.

GCVS100 assessed in WSDB formula showed similar effects than $\mathrm{NaCl}$. The addition of GCVS100 or $\mathrm{NaCl}$ to WSDB caused reduction of gas production during fermentation. Meanwhile, the coefficient of gas retention did not show significant differences between the treatments, due to WSDB formulation include compounds promoter of strengthening of the gluten structure of the dough that masked $\mathrm{NaCl}$ and GCVS100 effect. In this way, $\mathrm{NaCl}$ and GCVS100 led to decrease dough development according to less gas production.

WSDB baking parameters revealed that bread loaf specific volume was significantly higher for WSDB without $\mathrm{NaCl}$ or GCVS100, in agreement with fermentation results. Texture profile analysis of WSDB did not showed changes in crumb firmness and springiness when $\mathrm{NaCl}$ or GCVS100 is added.

Conclusions. The addition of GCVS100 in WSDB caused a similar effect to $\mathrm{NaCl}$. The results of the present study suggest that GCVS100 exhibits a potential use to obtain sodium-free WSDB. 


\section{Introduction}

According to the World Health Organization, it is recommended to consume $5 \mathrm{~g}$ of sodium chloride (or $2 \mathrm{~g}$ of sodium) per day (WHO, 2012). Globally, average daily dietary salt intake is much higher than this recommendation and the majority of salt intake comes from commercially manufactured foods (Brown et al., 2009; Newson et al., 2013).

Salt reduction programs have been shown to be highly cost-effective (Cobiac, 2010), hence the urgency to implement strategies and policies to address the issue of reducing salt intake. To carry out this approach certain topics should be taken in account. First, salt as an ingredient influences textural and stabilities properties of commercial food, hence salt reduction requires advances in food technology (Doyle and Glass, 2010). Second, salt affects food flavor, so it is important to work on consumer perception such as sensory reeducation, unaccustomed the palate to excessive salty taste and re-feeling the original flavors of food, likewise, modify behaviors in the domestic habit, method of shopping and food preparation (Zandstra et al., 2016; Ding et al., 2020). The successful reduction of sodium chloride in food is a long process that depends on solving technological issues in each of the food industries, awakening the healthy conscience of consumers, and an adequate complement of the food industry with government programs (FSA, 2012; FDA, 2016].

Bread is one of the major contributors to dietary sodium intake (Ni Mhurchu et al., 2010). Sodium content of bread is relatively low, however people consume highly this group of foods which contributes $35 \%$ to $50 \%$ of the sodium consumption (Beer-Borst et al., 2009; Quilez and Salas-Salvado, 2012). As the consumption of bread is approximately $70 \mathrm{Kg} / \mathrm{Hab}$ / year, it provides $3.2 \mathrm{~g}$ of sodium chloride per day, around $40 \%$ of the total salt ingested (Conde Molina et al., 2020). This estimation clearly demonstrates the relevance of reducing sodium content in breads.

Sodium chloride replacement is not an easy task to do on bread. Since sodium chloride contributes three main functions in the dough: enhance flavor, reduce gas production by inhibiting yeast activity, strengthen gluten structures of dough producing larger protein network (Miller \& Hoseney, 2008; Silow et al., 2016). In many cases, taste is one of the most important challenge associated with substitution. This aspect can be achieved with combinations of: salts (KCl, calcium salts, magnesium salts), amino acids (lysine) and flavor enhancers (monosodium glutamate, nucleotides, yeast extract) (Bassett et al., 2014; Rafo et al., 2018). Moreover, sodium chloride has a significant impact on the bread making process. In order to understand the impact of sodium chloride replacement on the bakery products' technological process, its influence on dough processing has to be known.

Several studies have reported changes in dough rheology and bread quality properties when sodium is substituted in breads (Nogueira et al., 2015; Pasqualone et al., 2019), however such characteristics depend on bread recipe and process. Thus, the aim of this work was to investigate the sodium substitution in white slice dairy bread (WSDB), which represents to be the most important industrial bread consumed in Argentina. For this purpose, Granolife CV Sustisal 100 substitute was assessed in order to evaluate the influence of sodium chloride replacement on fermentative and rheological properties on flour and then on WSDB formulation. 


\section{Materials and methods}

\section{Materials}

Granolife CV Sustisal 100 (GCVS100, blend of $\mathrm{KCl}$ and flavor enhancers) (Granotec Argentina) was studied as $\mathrm{NaCl}$ substitute.

The Argentinian wheat flour analyzed presented the following values: humidity 14.20 $\%$ (ISO 712), ashes $0.64 \%$ (AOAC 923.03), wet gluten $28 \%$, index gluten $99 \%$, dry gluten $10 \%$ (AACC 38-12), falling number $410 \mathrm{~s}$ (AACC 56-81B), damaged starch $9 \%$ (AACC 76-33). The alveograph parameters were tenacity/extensibility (P/L) 1.2 and deformation work (W) $31010^{-4} \mathrm{~J}$ (AACC 54-30A). Stability of dough was $13.5 \mathrm{~min}$ (modified method AACC 54-60.01).

\section{Rheological properties of wheat flour dough}

The effect of $\mathrm{NaCl}$ replacement was studied in wheat flour dough. To do this, three conditions were evaluated: flour $(\mathrm{F})$ as control, flour $+\mathrm{NaCl}$ ( $2 \%$ flour weight basis) $(\mathrm{F}+\mathrm{NaCl})$ as reference, flour + GCVS100 (2\% flour weight basis) $(\mathrm{F}+\mathrm{GCVS100})$ as substitution.

Doughs (55\% hydration) were kneaded for $1 \mathrm{~min}$ at slow speed and $4 \mathrm{~min}$ at medium speed in a bakery mixer (model A-120T, Hobart, USA). Then, $315 \mathrm{~g}$ of doughs were tested in the Reofermentograph, applying $2 \mathrm{~kg}$ weights over dough, at $28^{\circ} \mathrm{C}$ for $3 \mathrm{~h}$. Fermentation assays allowed to obtain gas evolution and dough development curves. Additionally, $75 \mathrm{~g}$ dough was analyzed in Mixolab (Chopin, France) to determine instant dough consistency (C1, Nm) at $100 \mathrm{rpm}$ (Chopin, 2012).

The rheological characteristics of dough were measured using Mixolab according to modified AACCI Approved Methods 54-60.01. Results were analyzed by Chopin Mixolab software (Version 3.14, Chopin, France).

\section{Rheological and baking properties of white slide diary bread}

GCVS-100 was assessed in WSDB. Formulation for WSDB was: $1 \mathrm{~kg}$ flour, $12 \mathrm{~g}$ dry yeast, $20 \mathrm{~g} \mathrm{NaCl}, 75 \mathrm{~g}$ sugar, $30 \mathrm{~g}$ of vegetable oil, $20 \mathrm{~g}$ milk powder, $10 \mathrm{~g}$ wheat gluten, 3.5 $\mathrm{g}$ calcium propionate, $15 \mathrm{~g}$ Toler Miga Bollo Directo (blend of ascorbic acid and enzymes (alpha-amylases, xylanases, lipases), Granotec Argentina), $650 \mathrm{ml}$ water. Test conditions were: WSDB without $\mathrm{NaCl}$ as control, WSDB with $\mathrm{NaCl}$ as reference, WSDB with GCVS100 as substitution. Doughs were prepared using a bakery mixer (model A-120T, Hobart, USA). They were kneaded for $1 \mathrm{~min}$ at slow speed, $2 \mathrm{~min}$ at medium speed and 3 min at fast speed.

In order to study fermentation stage, $100 \mathrm{~g}$ of doughs were analyzed in the Reofermentograph, applying $2 \mathrm{~kg}$ weights over dough, at $28{ }^{\circ} \mathrm{C}$ for $3 \mathrm{~h}$ (Chopin, 1996). Instant dough consistency was also determined in Mixolab (Chopin, France) as described above for flour dough.

Otherwise, breads were prepared. Doughs obtained were divided into $500 \mathrm{~g}$ portions of spherical shape and rest for $10 \mathrm{~min}$. Then, doughs were passed through a dough pressing machine (model 0203, Indupan, Argentina). Subsequently, pieces were rolled down like tube shape and placed into pans $(20 \mathrm{~cm}$ length, $10 \mathrm{~cm}$ width, $10 \mathrm{~cm}$ height). For each formulation, two sequence of three pans were placed in the fermentation camera at $36{ }^{\circ} \mathrm{C}$ for $90 \mathrm{~min}, \mathrm{RH}$ $=80 \%$. Three loaves of bread were baked in an oven (RPO4A10-2, Eurofours, France) at 150 
${ }^{\circ} \mathrm{C}$ with lidded pans for $35 \mathrm{~min}$ and another three loaves of bread were baked without the lids for $40 \mathrm{~min}$. Breads with lid reached their baking time 5 min earlier because the lid accelerated the baking time. Loaves baked without the lids were left to cool to determine specific volume. Otherwise cool loaves baked with the lids were packed and stored at room temperature until texture analysis.

Bread baking quality was evaluated by loaf specific volume, crumb firmness and springiness textural parameters. Loaves volume was measured by rapeseed displacement according to AACC 10-05 method, using bread loaf volumeter equipment (Chopin, France). Specific volume of the loaves was calculated from the measured volume and weight, obtained by direct measure. Texture profile analysis was analyzed in order to study the structure of the crumb. It was carried out using QTS Farnel Texture Analyser (Brookfield). Crumb firmness was determined according to the method AACC 74-09. Slices (25 mm-thickness) were compressed with a $36 \mathrm{~mm}$ diameter cylindrical probe at a speed of $2 \mathrm{~mm} / \mathrm{s}$ until a deformation, to a total deformation of $10 \mathrm{~mm}$ and a trigger force of $4 \mathrm{~g}$ were the selected settings. Springiness parameter was determined by texture profile analysis (TPA). Bread slices (50 mm-thickness) were compressed twice using a $25.4 \mathrm{~mm}$ diameter cylindrical probe (TA 11) and a test speed of $1.0 \mathrm{~mm} / \mathrm{s}$; to a total deformation of $15 \mathrm{~mm}$ and a trigger force of $4 \mathrm{~g}$ were the selected settings. Bread slices (50 mm-thickness) were compressed twice to give a TPA from which springiness textural parameter was obtained (Bourne et al. 2002). Crumb firmness and springiness textural parameters were obtained through Textute Pro v. 2.1 software. The test was carried out at different times of storage $(5,10$ and 15 days) in order to evaluate bread aging.

\section{Statistical analysis}

Data were expressed as means \pm standard deviations for triplicate determination. Statistical analysis was performed using Microsoft Excel 2010. Significant differences were determined at $\mathrm{p}<0.05$ by analysis of variance (ANOVA) and Tukey's HSD test. The analyses were carried out using the software Statgraphics Centurion XVII (Statpoint Technologies, USA).

\section{Results and discussion}

\section{Flour dough rheology evaluation}

Initially, GCVS100 substitute was evaluated in an Argentinian wheat flour dough (F). To point view, this type of flour presents some high quality parameters as wet gluten $28 \%$, $\mathrm{P} / \mathrm{L} 1.20$, W $31010^{-4} \mathrm{~J}$, stability of dough $13.5 \mathrm{~min}$, being suitable to produce industrial WSDB.

Dough rheological properties in $\mathrm{F}+\mathrm{NaCl}$ and $\mathrm{F}+\mathrm{GCVS} 100$ presented significantly differences during fermentation in comparison to $\mathrm{F}$ (Table 1). The volume of gas produced $\left(\mathrm{V}_{\mathrm{T}}\right)$ in both cases was inferior $(\mathrm{p}<0.05)$ than $\mathrm{F}$, evidencing the reduction of yeast activity caused by the presence of this type of salts. Chloride salt influences on yeast metabolism by its osmotic pressure, inhibiting yeast growth and leading to lower $\mathrm{CO}_{2}$ production (Jekle et al., 2019). Furthermore, maximum height of gas production curve $\left(\mathrm{H}_{\mathrm{m}}{ }^{\prime}\right)$ significantly decreased $(\mathrm{p}<0.05)$ in $\mathrm{F}+\mathrm{NaCl}$ and $\mathrm{F}+\mathrm{GCVS} 100$ in relation to $\mathrm{F}$, as consequence of the fact that the $\mathrm{CO}_{2}$ produced by the yeast during fermentation was reduced. Similar influences on $\mathrm{H}_{\mathrm{m}}$ value by salt addition have also been previously reported (Miller and Jeong, 2014; 
McCann and Day, 2013). Although $\mathrm{NaCl}$ and GCVS100 led to reduce $\mathrm{V}_{\mathrm{R}}$ and $\mathrm{V}_{\mathrm{T}}$ values, they significantly increased $(\mathrm{p}<0.05)$ the coefficient of gas retention $\left(\mathrm{V}_{\mathrm{R}} / \mathrm{V}_{\mathrm{T}}\right)$ value. This fact indicated that an improvement of the gluten network occurs with the addition of $\mathrm{NaCl}$ or GCVS100. $\mathrm{NaCl}$ produces a strengthening effect on the gluten network, which makes the dough more capable of retaining the gas released by fermentation (Mohammed et al., 2012).

Table 1

Effect of $\mathrm{NaCl}(\mathrm{F}+\mathrm{NaCl})$ and GCVS100 (F+GCVS100) on flour (F) dough rheological properties during fermentation

\begin{tabular}{|l|c|c|c|}
\hline Rheofermentograph & F & F+NaCl & F+GCVS100 \\
\hline Curve of gas & $(1604 \pm 8)^{\mathrm{a}}$ & $(1204 \pm 12)^{\mathrm{b}}$ & $(1227 \pm 13)^{\mathrm{b}}$ \\
\hline $\mathrm{V}_{\mathrm{T}}($ volume of gas produced, mL) & $(1256 \pm 10)^{\mathrm{a}}$ & $(1058 \pm 8)^{\mathrm{b}}$ & $(1057 \pm 7)^{\mathrm{b}}$ \\
\hline $\mathrm{V}_{\mathrm{R}}($ volume of gas retained, mL) & $(348 \pm 9)^{\mathrm{a}}$ & $(146 \pm 8)^{\mathrm{a}}$ & $(170 \pm 9)^{\mathrm{c}}$ \\
\hline $\mathrm{V}_{\mathrm{L}}($ volume of gas lost, mL) & $(78 \pm 1)^{\mathrm{a}}$ & $(89 \pm 2)^{\mathrm{b}}$ & $(86 \pm 2)^{\mathrm{b}}$ \\
\hline $\mathrm{V}_{\mathrm{R}} / \mathrm{V}_{\mathrm{T}}($ coefficient of gas retention, \%) & $(54 \pm 1)^{\mathrm{a}}$ & $(40 \pm 2)^{\mathrm{b}}$ & $(42 \pm 2)^{\mathrm{b}}$ \\
\hline $\mathrm{H}_{\mathrm{m}}($ maximum height, mm) & $(82 \pm 1)^{\mathrm{a}}$ & $(82 \pm 2)^{\mathrm{b}}$ & $(84 \pm 3)^{\mathrm{b}}$ \\
\hline $\mathrm{T}_{\mathrm{x}}($ time needed to start losing gas, min) & \multicolumn{3}{|l|}{} \\
\hline Curve of dough development & $(33 \pm 1)^{\mathrm{a}}$ & $(30 \pm 2)^{\mathrm{a}}$ & $(29 \pm 2)^{\mathrm{a}}$ \\
\hline $\mathrm{H}_{\mathrm{m}}($ maximum dough height, mm) & $(27 \pm 1)^{\mathrm{a}}$ & $(30 \pm 2)^{\mathrm{a}}$ & $(29 \pm 2)^{\mathrm{a}}$ \\
\hline $\mathrm{H}($ dough height after 3 h, mm) & $(2.87 \pm 0.15)^{\mathrm{a}}$ & $(2.84 \pm 0.09)^{\mathrm{a}}$ & $(2.77 \pm 0.11)^{\mathrm{a}}$ \\
\hline Dough consistency $(\mathrm{Nm})$ &
\end{tabular}

Means with different letters in each row are statistically different $(\mathrm{P}<0.05)$.

Maximum dough height of the dough development curve $\left(\mathrm{H}_{\mathrm{m}}\right)$ were similar for all cases. This suggests that the effect the salts to increase $V_{R} / V_{T}$ compensate the low $V_{T}$ value, thereby leading to similar $\mathrm{H}_{\mathrm{m}}$.

Mixolab was used in order to analyze the replacement of $\mathrm{NaCl}$ on flour dough by GCVS100 during mixing-heating-cooling. Therefore, changes associated with dough during mixing due to ingredients hydration, heating due to protein weakening and starch gelatinization, and cooling due to starch gelling, were registered by following dough consistency (Figure 1, Table 2). Results showed that NaCl and GCVS100 significantly decrease $(\mathrm{p}<0.05)$ water absorption (WA). In fact chloride salt, due to its ionic nature, interacts with water and macromolecules from the dough complex reducing the WA of wheat flour. As consequence of higher hydrophobic interactions, gluten proteins interact to a higher extent leading to a reduced water uptake capacity (Voinea et al., 2020; Lopes et al., 2017).

Concerning dough stabilities, values significantly increased $(\mathrm{p}<0.05)$ with $\mathrm{NaCl}$ or GCVS100 addition. Although $\mathrm{F}+\mathrm{NaCl}$ showed higher stability than F+ GCVS100, 22 Vs. 18 min, they are both considered to be high stability parameter to WSDB making process. This effect may be attributed to the fact that greater hydrophobic interactions between gluten proteins leads to a closer molecular structure between these proteins. The strengthening effect of wheat flour dough has been reported due to addition of chloride salts in dough (Mohammed et al., 2012).

Protein weakening pattern (C2) showed no significant difference when $\mathrm{NaCl}$ or GCVS100 was added to the flour dough, during heating. Meanwhile with the increase in temperature, the incorporation of $\mathrm{NaCl}$ or GCVS100 to the dough exhibited lower values $(\mathrm{p}<0.05)$ of the starch gelatinization range $(\mathrm{C} 3-\mathrm{C} 2)$ compared to $\mathrm{F}$. These data may be related 
that the presence of these types of salt may affect swelling starch, remaining intact the starch granules for a long time before fragmentation (Nogueira et al., 2015). Furthermore, parameter $\mathrm{C} 4-\mathrm{C} 3$ had higher values $(\mathrm{p}<0.05)$ for $\mathrm{F}+\mathrm{NaCl}$ and $\mathrm{F}+\mathrm{GCVS} 100$ than $\mathrm{F}$, indicating that the addition of $\mathrm{NaCl}$ or GCVS100 in dough improved the stability of the starch gel when heated.

Significant differences $(\mathrm{p}<0.05)$ were observed in the dough consistency at cooling $(\mathrm{C} 4$ $\mathrm{C5}$ ) in the presence of $\mathrm{NaCl}$ or GCVS100. In these cases, retrogradation of the starch was increased. It was reported (Krupa-Kozak et al., 2012) that retrogradation of the starch changes when calcium salts were added to fortified formulas in Mixolab. This study suggests that anions modified the starch chains' recrystallisation. Other works reported that $\mathrm{NaCl}$ reduces the retrogradation of starches during storage (Baker and Rayas-Duarte, 1998; Beck et al., 2012), however retrogradation of the starch effect caused for $\mathrm{NaCl}$ in wheat flour dough was not reported previously in Mixolab. In our case of study, the effect of increase of retrogradation of the starch due to $\mathrm{NaCl}$ or GCVS100 addition may not be remarkable, as WSDB formula contains Toler Migo Bollo Directo (which includes enzymes) that promotes the mean anti-staling characteristic in the final product.

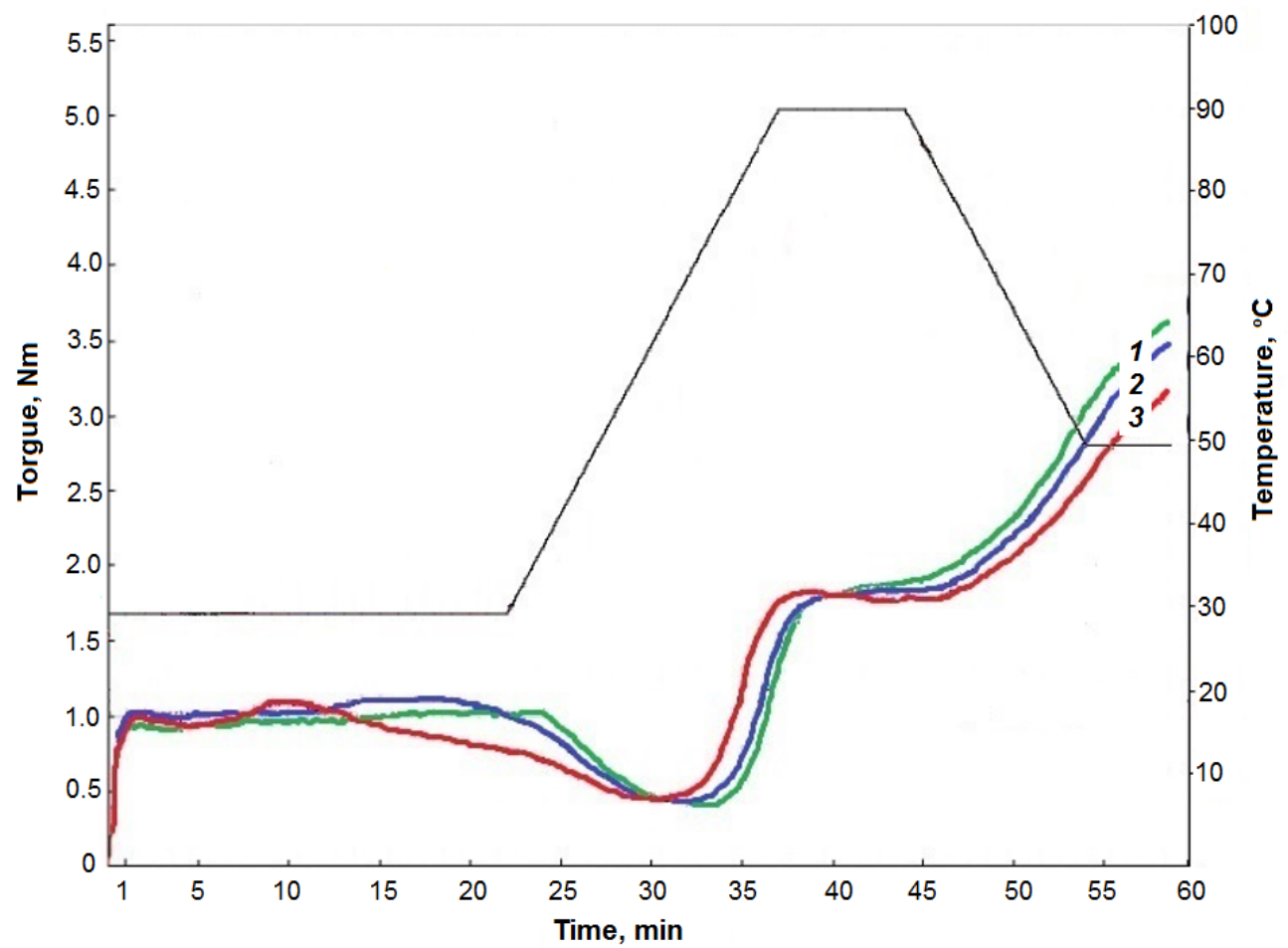

Figure 1. Effect of $\mathrm{NaCl}(\mathrm{F}+\mathrm{NaCl})$ and GCVS100 (F+GCVS100) on flour (F) dough consistency determined by Mixolab:

1 - F, 2 - F+NaCl, 3 - F+ GCVS100 
Table 2

Effect of $\mathrm{NaCl}(\mathrm{F}+\mathrm{NaCl})$ and GCVS100 (F+GCVS100) on flour $(\mathrm{F})$ dough rheological properties during Mixolab analysis

\begin{tabular}{|l|c|c|c|}
\hline Mixolab & F & F+NaCl & F+GCVS100 \\
\hline WA (water absorption, \%) & $(58.0 \pm 0.1)^{\mathrm{a}}$ & $(56.3 \pm 0.3)^{\mathrm{b}}$ & $(56.1 \pm 0.1)^{\mathrm{b}}$ \\
\hline Stability (min) & $(13.5 \pm 0.7)^{\mathrm{a}}$ & $(22.3 \pm 0.5)^{\mathrm{b}}$ & $(18.2 \pm 0.4)^{\mathrm{c}}$ \\
\hline C2 (protein weakening, Nm) & $(0.45 \pm 0.02)^{\mathrm{a}}$ & $(0.41 \pm 0.02)^{\mathrm{a}}$ & $(0.44 \pm 0.02)^{\mathrm{a}}$ \\
\hline C3 (starch gelatinization, Nm) & $(1.83 \pm 0.01)^{\mathrm{a}}$ & $(1.73 \pm 0.02)^{\mathrm{b}}$ & $(1.76 \pm 0.02)^{\mathrm{b}}$ \\
\hline $\begin{array}{l}\text { C3-C2 (starch gelatinization } \\
\text { range, Nm) }\end{array}$ & $(1.38 \pm 0.02)^{\mathrm{a}}$ & $(1.32 \pm 0.02)^{\mathrm{b}}$ & $(1.32 \pm 0.02)^{\mathrm{b}}$ \\
\hline C4 (hot gel stability, Nm) & $(1.76 \pm 0.04)^{\mathrm{a}}$ & $(1.89 \pm 0.02)^{\mathrm{b}}$ & $(1.86 \pm 0.04)^{\mathrm{b}}$ \\
\hline $\begin{array}{l}\text { C4-C3 (cooking stability } \\
\text { range, Nm) }\end{array}$ & $(-0.07 \pm 0.04)^{\mathrm{a}}$ & $(0.16 \pm 0.02)^{\mathrm{b}}$ & $(0,10 \pm 0.04)^{\mathrm{b}}$ \\
\hline $\begin{array}{l}\text { C5 }(\text { starch retrogradation in the } \\
\text { cooling phase, Nm) }\end{array}$ & $(3.21 \pm 0.02)^{\mathrm{a}}$ & $(3.65 \pm 0.02)^{\mathrm{b}}$ & $(3.52 \pm 0.02)^{\mathrm{c}}$ \\
\hline C5-C4 (gelling, Nm) & $(1.45 \pm 0.02)^{\mathrm{a}}$ & $(1.76 \pm 0.02)^{\mathrm{b}}$ & $(1.66 \pm 0.03)^{\mathrm{c}}$ \\
\hline
\end{tabular}

Means with different letters in each row are statistically different $(\mathrm{P}<0.05)$.

\section{WSDB dough rheology and bread evaluation}

GCVS100 was assessed in WSDB formula in order to evaluate dough rheology and bread quality. $\mathrm{NaCl}$ and GCVS100 caused changes in the fermentative properties of the dough (Table 3 ). $\mathrm{V}_{\mathrm{T}}$ parameter significantly decreased $(\mathrm{p}<0.05)$ when $\mathrm{NaCl}$ or GCVS100 was added to WSDB. It had already been observed and discussed in the wheat flour assays that the presence of $\mathrm{NaCl}$ or GCVS100 changes the yeast growth environment to be less favourable, thus reducing the amount of $\mathrm{CO}_{2}$ produced. The influence of $\mathrm{NaCl}$ in WSDB was even greater than that of GCVS100, being $\mathrm{V}_{\mathrm{T}}$ of WSDB with $\mathrm{NaCl}$ lower than $\mathrm{V}_{\mathrm{T}}$ of WSDB with GCVS100.

$\mathrm{H}^{\prime}{ }_{m}$ of gas production curves were significantly lower $(\mathrm{p}<0.05)$ for dough WSDB with $\mathrm{NaCl}$ or GCVS100 comparing to WSDB without salt. These results correlated with less quantity of gas produced. $\mathrm{H}_{\mathrm{m}}$ of the dough development curve also decreased due to $\mathrm{NaCl}$ and GCVS100 effect.

Additionally, $V_{R} / V_{T}$ did not show significant differences between the treatments. This may be to the fact that WSDB formulation has ingredients, such as gluten, oxidizing agents and enzymes, which promote strengthening of the gluten structure of the dough (Aamodt et al., 2003; Steffolani et al., 2010), leading to retain the gas released during fermentation. As consequence, it was noticed that WSDB without $\mathrm{NaCl}$ presented significantly higher $\mathrm{H}_{\mathrm{m}}$ value $(\mathrm{p}<0.05)$ than in the case of WSDB with $\mathrm{NaCl}$ or GCVS100. Thus, WSDB ingredients probably lead to strengthening of the dough mitigating the absence of $\mathrm{NaCl}$ and GCVS100 on the gas retention effect. On the other hand, the lack of this salts in WSDB produces higher gas production, thereby increases development of the dough. 
Table 3

Effect of NaCl and GCVS100 on WSDB dough rheological properties during fermentation

\begin{tabular}{|l|c|c|c|}
\hline Rheofermentograph & $\begin{array}{c}\text { WSDB } \\
\text { without NaCl }\end{array}$ & $\begin{array}{c}\text { WSDB with } \\
\text { NaCl }\end{array}$ & $\begin{array}{c}\text { WSDB with } \\
\text { GCVS100 }\end{array}$ \\
\hline Curve of gas & $(1029 \pm 8)^{\mathrm{a}}$ & $(671 \pm 12)^{\mathrm{b}}$ & $(721 \pm 13)^{\mathrm{c}}$ \\
\hline $\mathrm{V}_{\mathrm{T}}($ volume of gas produced, mL) & $(988 \pm 10)^{\mathrm{a}}$ & $(665 \pm 8)^{\mathrm{b}}$ & $(715 \pm 7)^{\mathrm{c}}$ \\
\hline $\mathrm{V}_{\mathrm{R}}($ volume of gas retained, $\mathrm{mL})$ & $(31 \pm 9)^{\mathrm{a}}$ & $(6 \pm 8)^{\mathrm{b}}$ & $(6 \pm 9)^{\mathrm{b}}$ \\
\hline $\mathrm{V}_{\mathrm{L}}($ volume of gas lost, mL) & $(97 \pm 1)^{\mathrm{a}}$ & $(99 \pm 2)^{\mathrm{a}}$ & $(99 \pm 2)^{\mathrm{a}}$ \\
\hline $\begin{array}{l}\mathrm{V}_{\mathrm{R}} / \mathrm{V}_{\mathrm{T}}(\text { coefficient of gas retention, } \\
\%\end{array}$ & $(55 \pm 1)^{\mathrm{a}}$ & $(41 \pm 2)^{\mathrm{b}}$ & $(40 \pm 2)^{\mathrm{b}}$ \\
\hline $\mathrm{H}_{\mathrm{m}}($ maximum height, mm) & $(139 \pm 3)$ & - & - \\
\hline $\begin{array}{l}\mathrm{T}_{\mathrm{x}}(\text { time needed to start losing gas, } \\
\text { min) }\end{array}$ & \multicolumn{3}{|l|}{} \\
\hline Curve of dough development & $(58 \pm 1)^{\mathrm{a}}$ & $(38 \pm 2)^{\mathrm{b}}$ & $(35 \pm 2)^{\mathrm{b}}$ \\
\hline Hm (maximum dough height, mm) & $(58 \pm 1)^{\mathrm{a}}$ & $(38 \pm 1)^{\mathrm{b}}$ & $(35 \pm 2)^{\mathrm{b}}$ \\
\hline H (dough height after 3 h, mm) & $(1.91 \pm 0.12)^{\mathrm{a}}$ & $(1.79 \pm 0.09)^{\mathrm{a}}$ & $(1.85 \pm 0.07)^{\mathrm{a}}$ \\
\hline Dough consistency $(\mathrm{Nm})$ &
\end{tabular}

Means with different letters in each row are statistically different $(\mathrm{P}<0.05)$.

The effect of $\mathrm{NaCl}$ and GCVS100 on bread quality indicators is shown in Table 4. When substitute GCVS100 was evaluated in WSDB preparation, baking results showed that bread loaf specific volume was significantly higher $(\mathrm{p}<0.05)$ for WSDB without $\mathrm{NaCl}$ than for WSDB with each salt, in agreement with the data analyzed above concerning to the fermentation parameters of the WSDB tests. This is agreeing to other works which reported that bread with less salt has been found to have higher volume of dough (Lynch et al., 2009; Beck et al. 2012).

Textural parameters were measured at 0,5 and 15 days, in order to evaluate the evolution of the crumb during 15 days, which is the normal shelf life and sale of WSDB. It was noticed that significantly differences were not found in crumb firmness and springiness between the three bread treatments. WSDB formulation includes enough ingredients that contribute to stand suitable textural properties of bread, irrespective of presence or absence of $\mathrm{NaCl}$. Previous report (Lynch et al., 2009) noticed that $\mathrm{NaCl}$ helps to strengthen and improve the gluten network of the dough, leading to produce uniform crumb structure. In our study, this effect was not observed as consequence of the integral WSDB formulation.

Furthermore, crumb firmness was similar between treatments along 15 days, indicating that $\mathrm{NaCl}$ and GCVS100 did not influence the retrogradation of the starch during WSDB storage. It was reported (Baker and Rayas-Duarte, 1998) that $\mathrm{NaCl}$ reduced the retrogradation of starches during bread storage, due to the fact that large ions, as $\mathrm{Na}^{+}$, are entrapped in the molecules compared to the small $\mathrm{H}^{+}$ions. However, this research suggests that retrogradation of starch caused by $\mathrm{NaCl}$ may be masked by others ingredients in the bread recipe. Therefore, the effect of $\mathrm{NaCl}$ or some substitute on bread shelf life should be analyzed according each bread formulation. 
Effect of $\mathrm{NaCl}$ and GCVS100 on indicators of bread quality

\begin{tabular}{|c|c|c|c|}
\hline Rheofermentograph & $\begin{array}{l}\text { WSDB without } \\
\mathrm{NaCl}\end{array}$ & $\begin{array}{l}\text { WSDB with } \\
\mathrm{NaCl}\end{array}$ & $\begin{array}{l}\text { WSDB with } \\
\text { GCVS100 }\end{array}$ \\
\hline Bread weight (g) & $(429 \pm 1)^{\mathrm{a}}$ & $(428 \pm 2)^{\mathrm{a}}$ & $(431 \pm 2)^{\mathrm{a}}$ \\
\hline Bread volume (mL) & $(2680 \pm 4)^{\mathrm{a}}$ & $(2500 \pm 7)^{\mathrm{b}}$ & $(2530 \pm 4)^{\mathrm{c}}$ \\
\hline $\begin{array}{l}\text { Bread loaf specific volume } \\
(\mathrm{mL} / \mathrm{g})\end{array}$ & $(6.25 \pm 0.03)^{\mathrm{a}}$ & $(5.84 \pm 0.02)^{\mathrm{b}}$ & $(5.87 \pm 0.02)^{\mathrm{b}}$ \\
\hline \multicolumn{4}{|l|}{ Crumb firmness $(\mathrm{g})$} \\
\hline 5 (days) & $(475 \pm 9)^{\mathrm{a}}$ & $(480 \pm 6)^{\mathrm{a}}$ & $(479 \pm 7)^{\mathrm{a}}$ \\
\hline 10 (days) & $(927 \pm 7)^{\mathrm{a}}$ & $(832 \pm 6)^{\mathrm{a}}$ & $(828 \pm 4)^{\mathrm{a}}$ \\
\hline 15 (days) & $(1395 \pm 12)^{\mathrm{a}}$ & $(1401 \pm 11)^{\mathrm{a}}$ & $(1405 \pm 9)^{\mathrm{a}}$ \\
\hline \multicolumn{4}{|l|}{ Springiness } \\
\hline 5 (days) & $(0.93 \pm 0.01)^{\mathrm{a}}$ & $(0.93 \pm 0.01)^{\mathrm{a}}$ & $(0.93 \pm 0.01)^{\mathrm{a}}$ \\
\hline 10 (days) & $(0.92 \pm 0.01)^{\mathrm{a}}$ & $(0.93 \pm 0.01)^{\mathrm{a}}$ & $(0.92 \pm 0.01)^{\mathrm{a}}$ \\
\hline 15 (days) & $(0.92 \pm 0.01)^{\mathrm{a}}$ & $(0.93 \pm 0.01)^{\mathrm{a}}$ & $(0.92 \pm 0.01)^{\mathrm{a}}$ \\
\hline
\end{tabular}

Means with different letters in each row are statistically different $(\mathrm{P}<0.05)$.

This work does not include sensory traits to study the influence of the substitute on the taste of WSDB. Perhaps a dosage of $20 \mathrm{~g}$ of GCVS100 / $1 \mathrm{~kg}$ of flour (as indicated in the recipe) will not be enough to affect the flavor of the bread. Moreover, GCVS100 includes flavor enhancers that masked "metallic" and "bitter" after-taste imparted by potassium ions. Further research will be necessary to evaluate sensory characteristics.

\section{Conclusion}

The current research has shown that GCVS100 fulfits its function as $\mathrm{NaCl}$ substitute adequately for industrial WSDB production.

The addition of GCVS100 in WSDB caused a similar effect to $\mathrm{NaCl}$. Both ingredients lead to decrease gas production and dough development during fermentation stage. Consequently, baking test showed that bread loaf specific volume decreased when $\mathrm{NaCl}$ or GCVS100 is added.

Texture profile analysis of WSDB did not showed changes in crumb firmness and springiness when $\mathrm{NaCl}$ or GCVS100 is added. WSDB contains several ingredients, as gluten, oxidizing agents and enzymes, which confer a preponderant effect to textural characteristics.

The results of the present study suggest that GCVS100 exhibits a potential use to obtain sodium-free WSDB.

Acknowledgements. The authors would like to express their appreciation to Granotec Argentina for financial support of this study. Data collection for this study was undertaken while DCM worked for Granotec Argentina (GA). VA works for GA. CQ has no conflicts of interest to declare.The views expressed are entirely those of the authors and do not necessarily reflect GA policy. 


\section{References}

Aamodt A., Magnus E.M., Faergestad E.M.. (2003), Effect of flour quality, ascorbic acid, and DATEM on dough rheological parameters and hearth loaves characteristics, J. Food Sci., 68, pp. 2201-10.

Baker L.A., Rayas-Duarte P. (1998), Retrogradation of amaranth starch at different storage temperatures and the effects of salt and sugars, Cereal Chem, 75, pp. 308-314.

Bassett M.N., Palacios T.P., Cipriano I., Cardoso P., Ferreira I.M.P.L.V.O., Samman N., Pinho O. (2014), Development of bread with $\mathrm{NaCl}$ reduction and calcium fortification: Study of its quality, J. Food Qual., 37, pp. 107-116.

Beck M., Jekle M., Becker T. (2012), Impact of sodium chloride on wheat flour dough for yeast-leavened products. II. Baking quality parameters and their relationship, J. Food Sci. Agric., 92(2), pp. 299-306.

Beer-Borst S., Costanza M.C., Pechère-Bertschi A., Morabia A. (2009), Twelve-year trends and correlates of dietary salt intakes for the general adult population of Geneva, Switzerland, Eur. J. Clin. Nutr., 63(2), pp. 155-164.

Bourne M.C. (2002), Food texture and viscosity: concept and measurement, Academic press, San Diego.

Brown I.J., Tzoulaki I., Candeias V. (2009), Salt intakes around the world: implications for public health, Int. J. Epidemiol., 38, pp.791-813.

Cobiac L.J., Vos T., Veerman J.L. (2010), Cost-effectiveness of interventions to reduce dietary intake, Heart, 96, pp. 1920-1925.

Conde Molina D., Quevedo C., Arqueros V. (2020), Evaluating effect of fat, sugar and flour substitutes on properties of white slice dairy bread, Int. J. Sci. R. in Biol. Sci., 7(6), pp. 70-77.

Chopin (1996), Rheofermentograph user's guide, Tripette \& Renaud.

Chopin (2012), Mixolab, user's guide, Tripette \& Renaud.

Ding J., Sun Y., Li Y., He J., Sinclair H., Du W., Wang H., Zhang P. (2020), Systematic review on international salt reduction policy in restaurants, Int J Environ Res Public Health., 17(24), 9570.

Doyle, M. E., Glass, K. A. (2010), Sodium reduction and its effect on food safety, food quality, and human health, Compr,Rev. Food Sci. Food Saf., 9(1), pp. 44-56.

Food and Drug Administration (2016), Office of foods and veterinary medicine, Center for food safety and applied nutrition draft guidance for industry: Target mean and upper bound concentrations for sodium in commercially processed, packaged, and prepared foods for voluntary sodium reduction goals, Available at:

https://www.fda.gov/Food/GuidanceRegulation/GuidanceDocumentsRegulatoryInformation/uc m494732.htm

Food Standards Agency (2012), New salt reduction targets published. Available at: http://webarchive.nationalarchives.gov.uk/20120206100416/http://food.gov.uk/news/newsarchiv e/2006/mar/salttargets

Jekle M., Necula A., Jekle M., Becker T. (2019), Concentration dependent rate constants of sodium substitute functionalities during wheat dough development, Food Res. Int., 116, pp. 346353.

Krupa-Kozak U., Altamirano-Fortoul R., Wronkowska M., Rosell, C. M. (2012), Breadmaking performance and technological characteristic of gluten-free bread with inulin supplemented with calcium salts, Eur. Food Res. Tech., 235(3), pp. 545-554.

Lopes M., Cavaleiro C., Ramos, F. (2017), Sodium reduction in bread: A role for glasswort (Salicornia ramosissima J. woods), Compr. Rev. Food Sci., Food, 16, pp. 1056-1071.

Lynch E.J., Dal Bello F., Sheehan E.M., Cashman K.D., Arendt E.K. (2009), Fundamental studies on the reduction of salt on dough and bread characteristics, Food Res. Int., 42(7), pp. 885891. 
McCann T.H., Day L. (2013) Effect of sodium chloride on gluten network formation, dough microstructure and rheology in relation to breadmaking, J. Cereal Sci., 57, pp. 444-452.

Miller R.A., Jeong J. (2014), Sodium reduction in bread using low-sodium sea salt, Cereal Chem., 9, pp. 41-44.

Mohammed I., Ahmed A.R., Senge B. (2012), Dough rheology and bread quality of wheatchickpea flour blends, Ind. Crops Prod., 36, pp. 196-202.

Ni Mhurchu C., Capelin C., Dunford E.K., Webster J.L., Neal B.C., Jebb, S.A. (2010), Sodium content of processed foods in the United Kingdom: analysis of 44,000 foods purchased by 21,000 households, Am. J. Clin. Nutr., 93(3), pp. 594-600.

Miller R.A., Hoseney R.C. (2008), Role of salt in baking, Cereal Foods World, 53(1), pp. 4 6.

Newson R.S., Elmadfa I., Biro G., Cheng Y., Prakash V., Rust P., et al. (2013), Barriers for progress in salt reduction in the general population: An international study, Appetite, 71, pp. 22 31.

Nogueira A.C., Kussano J.T., Steel, C.J. (2015), Sourdough reduces sodium in wheat flour doughs, Int. J. Food Sci. Technol., 50, pp. 2621-2629.

Pasqualone A., Caponio F., Pagani M.A., Summo, C., Paradiso V.M. (2019), Effect of salt reduction on quality and acceptability, Food Chem., 289, pp. 575-581.

Quilez J., Salas-Salvado J. (2012), Salt in bread in Europe: potential benefits of reduction, Nutr. Rev., 70(11), pp. 666-678.

Rafo A., Carcea M., Moneta E., Narducci V., Nicoli, S. (2018), Influence of different levels of sodium chloride of a reduced sodium salt substitute on volatiles formation and sensory quality of wheat bread, J. Cereal Sci., 79, pp. 519-526.

Shafisoltani M., Salehifar M., Hashemi M. (2014), Effects of enzymatic treatment using response surface methodology on the quality of bread flour, Food Chem., 148, pp. 176-83.

Silow C., Axel C., Zannini E., Arendt E.K. (2016), Current status of salt reduction in bread and bakery products - A review, J. Cereal Sci., 72, pp. 135-145.

Steffolani M.E., Ribotta P.D., Pérez G.T., León A.E. (2010), Effect of glucose oxidase, transglutaminase, and pentosanase on wheat proteins: relationship with dough properties and bread-making quality, J. Cereal Sci, 51, pp. 366-73.

Voinea A., Stroe S.G., Codină G. (2020). The effect of sodium reduction by sea salt and dry dourdough addition on the wheat flour dough rheological properties, Foods, 9(5), 610.

World Health Organization (2012), Guideline: Sodium intake for adults and children, WHO Document Production Services, Geneva.

Zandstra E.H., Lion R., Newson R.S. (2016), Salt reduction: Moving from consumer awareness to action, Food Qual. Prefer., 48, pp. 376-381. 